\title{
Histological and Morphometric Characteristics of the Corneal Layer of Buffalo Hoof Capsules
}

\author{
Características Histológicas y Morfométricas de la Capa Cornea \\ de las Cápsulas del Casco de Búfalo
}

B. M. Assis'; V. A. Vulcani²; F. J. F. Sant'Ana ${ }^{3}$; L. A. F. Silva ${ }^{1}$; C. R. O. Lima ${ }^{4}$; R. M. Santa Rita ${ }^{2}$ \& R. E. Rabelo ${ }^{2}$

ASSIS, B. M.; VULCANI, V. A.; SANT'ANA, F. J. F.; SILVA, L. A. F.; LIMA, C. R. O.; SANTA RITA, R. M. \& RABELO, R. E. Histological and morphometric characteristics of the corneal layer of buffalo hoof capsules. Int. J. Morphol., 35(4):1291-1297, 2017.

SUMMARY: This study aimed to evaluate the microstructure of the buffalo's hoof capsule using hystomorphometry and computerized light microscopy. The length, thickness, gap and number of epidermal papillae and the morphology of the corneal tubules of the hoof were described in this paper. This study used 56 hoof capsules from hooves of 14 adults - age ranging from 24 to 60 months old - female buffaloes of the Jafarabadi breed; weighing around $650 \mathrm{~kg}$. Fifty-six samples, 28 from thoracic limb and 28 from pelvic limbs, were analyzed, resulting in a total of 112 digits. Clinical specimens were collected at the coronary corium, laminar corium of the abaxial wall and pre-bulbar soles. The study concluded that the microstructure of the hoof capsule of buffalo hooves are made of epidermal papillae measuring 1,721.59 $\mathrm{mm}$ of length, $62.94 \mathrm{~mm}$ of thickness and $49.02 \mathrm{~mm}$ of gap between the papillae. This study determines that the coronary corium has more epidermal papillae than the laminar corium of the abaxial wall and pre-bulbar soles. The corneal tubules of the hoof capsules exhibit helical fashion and points to the possibility of applying this feature to the hooves of the biungulate species as well. In this research, we have been able to determine morphological parameters not yet described in scientific literature. These findings can be used in future comparative studies of healthy cattle and buffaloes and speculate evidence about the hooves' vulnerability facing different hoof diseases.

KEY WORDS: Epidermal papillae; Histomorphometry; Horn tubules; Keratinocytes; melanocytes.

\section{INTRODUCTION}

The hoof capsule from bovine hooves is divided in: wall, sole, heel, heel bulb and white line according to its formation, site and function (Greenough, 2007). This corneal structure is supported from the dermis on a modified epidermis. The combination of these structures constitutes the coronary and laminar corium. Modifications occurring in the epidermis result in epidermal papillae that take part in the proliferation of keratinocytes, which synthesize keratin and intercellular cement, substances which are linked to hoof quality and integrity (König et al., 2007).

Tubular keratins build a tubular compact and concentric structure in the hoof capsule not being seen in the modified epidermis. The number of corneal tubules connected by the intercellular cement directly affects the mechanical properties of the corneal tissue, especially its resistance, whose reduction might indicate a predisposition to hoof diseases. Among the risk factors, besides reduced hoof resistance, inappropriate animal handling, constant presence of contamination and excess humidity are presented as critical (Rabelo et al., 2015). However, these factors may not have the same importance in buffaloes, for they are apparently more resistant to hoof diseases when compared to cattle (Silva et al., 2015). Guccione et al. (2016) have observed in the Mediterranean Buffaloes breed similar hoof disease seen in the cattle, yet with lesser prevalence. The hoof diseases, mainly in dairy cattle are severe and responsible for sizeable losses in dairy farm have not been reported in buffalo farms yet (Silva et al.).

\footnotetext{
${ }^{1}$ Federal University of Goias, School of Veterinary and Zootechny - Goiânia, Goiás State, Brazil.

${ }^{2}$ Federal University of Goias, Regional Jataí, Goiás State, Brazil.

${ }^{3}$ University of Brasilia (UNB), Laboratory of Veterinary Pathological Diagnosis, Brasilia - District, Brazil.

${ }^{4}$ State University of Goias, Jataí, Goiás State, Brazil.

Fonte de fomento/processo: CNPq: National Council for Scientific and Technological Development (Conselho Nacional de Pesquisa e Desenvolvimento) (Process: 449753/2014-0). Fapeg: Research Support Foundation of the State of Goiás (Fundação de Amparo a Pesquisa do Estado de Goiás) (Process: 20122012267001141).
} 
Nevertheless, though hoof diseases are less frequent in buffaloes, there are unanswered questions on the subject, particularly related to hoof microstructure. On this matter, it is still necessary to characterize its microstructural aspects. This paper intends to determine parameters of the hoof capsules microstructure of buffalo hooves.

\section{MATERIAL AND METHOD}

Data collection occurred between July 2014 and August 2015, respecting the ethical precepts in animal experimentation and approved by the Ethics Committee of Animal Use, Deanery of Research and Innovation of UFG (CEUA-PRPI-UFG), Protocol \#20/2014.

This study used 56 hoof capsules from hooves of 14 adults - aged between 24 and 60 months old - non pregnant female buffaloes of the Jafarabadi breed; weight around $650 \mathrm{Kg}(1433=$ pounds $)$. All animals were pasture raised, without concentrated dietary supplementation, obtained from cold stores under the Federal Inspection Services, totaling 28 thoracic limb, 28 pelvic limb and 112 hooves. Of these 112 hooves, 56 were destined to histological and morphometric evaluations and to computerized light microscopy. Among the 56 hooves clinical specimens from the coronary corium, laminar corium of the abaxial wall and pre-bulbar sole, approximately $10 \mathrm{~mm}$ x $2 \mathrm{~mm}$, were collected, totaling three sampling points from each hoof. Samples were fixed in $10 \%$ buffered neutral formalin solution, embedded in paraffin and stained with hematoxylineosin (HE). Sample processing for histologic and morphometric evaluation followed the methodology described by Rabelo et al.

Histological sections analysis was conducted on a Leica DM 750 photomicroscope, with built-in digital camera ICC50 (HD-521420221). For morphometric assessments, including length, number and thickness of the epidermal papillae and its corresponding gaps in the coronary corium, laminar corium of the abaxial wall and sole, images were captured and analyzed using the LAS EZ® software. For epidermal papillae length, the measure between the dermis and basal layer at the apex of the papillae was considered. Papillae thickness was assessed from the left to the right basal layer. Papillae gaps were measured from the basal layer of one papilla to the basal layer of its adjacent papilla.

Material collected from the same regions and which were used for computerized light microscopy analysis respected the approximate dimension of $10 \mathrm{~mm} \times 10 \mathrm{~mm}$. During sample processing, the removal of dirt and soft tissue was ensured. The samples were stored in plastic packages and put at $-15^{\circ} \mathrm{C}$. Afterwards, samples were sent to the Material Engineering Laboratory at USP - São Carlos. First, the material was defrosted and embedded in T208 resin (Cristal ${ }^{\circledR}$, styrene monometer, MEK TGDM 50 catalyst and dimethylamine) in a proportion suitable for hardening for approximately three minutes. After then samples were sanded with water sandpaper number 80 to 2.200 for display of the hoof fragments using a Politriz Arotec - Aropol E® and, finally, analyzed in a light microscope (Zeiss AxioPlan 2ie, motorized and computerized, with built-in digital camera Axiocam HR - 3900 x 3900 pixels). Images were analyzed using KS400 from Zeiss software.

To analyze the results, T-test was used to compare two means, and analysis of variance (ANOVA) was used to compare the measure of the epidermal papillae of the thoracic limb, pelvic limb, the coronary corium and laminar corium of the abaxial wall and sole at a $5 \%$ significance level, according to Sampaio (2010).

\section{RESULTS AND DISCUSSION}

In the analyzed animals, greater stratification and papillae number were observed in the coronary corium, the laminar corium of the abaxial wall and sole respectively. (Figs. 1. A, B, C). Similar from other scientific research (Rabelo et al.), analysis from this study indicated that the basal layer is responsible for the renewal of keratinocytes, that are in constant mitosis and originate the spiny and granular layers (Figs. 1. D, E, F). From the complexity of this physiological mechanism in buffaloes, it might be inferred that this mechanism has fundamental importance for the integrity and quality of the hoof capsule (Tombolato et al., 2010).

Inside the keratinocytes, distributed in the hoof epidermal layer, an expressive number of melanosomes, rich in melanin was observed (Figs. 2. A, B). Macroscopically, these histological findings are translated into an intense pigmentation of buffalo hooves, allowing speculation that such pigmentation also plays a role in the resistance of their hooves.

As the correlation between pigmentation and resistance of buffalo hooves has not been the aim of scientific investigation, the subject requires scholar efforts to elucidate the factors encircling this feature. At the same time, however, greater quantities of melanin were observed at the base of the epidermal papillae, compared to the quantities of the referred pigment in the body and apex of the same structure. It was shown, also, that this pigment involves the cellular 

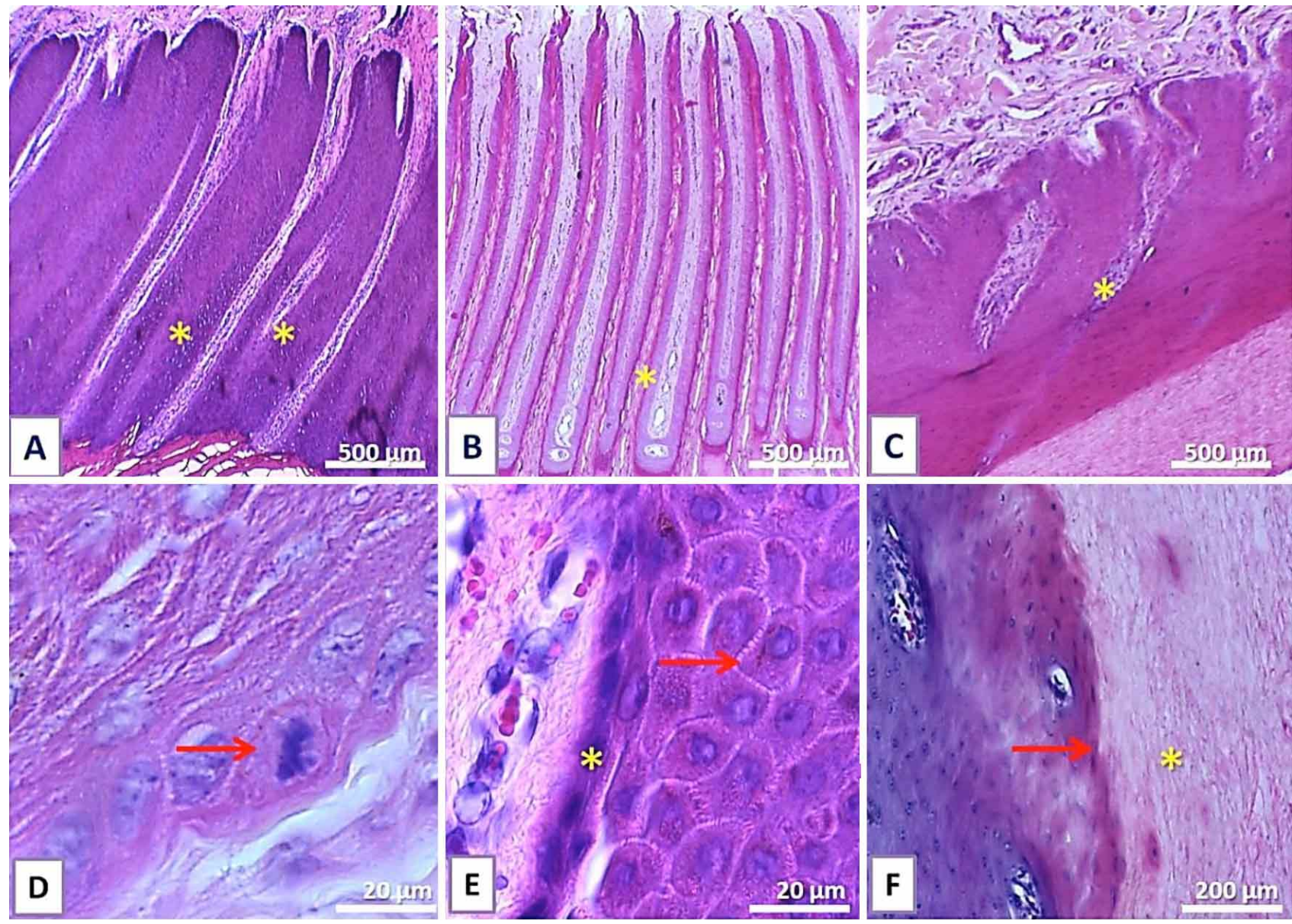

Fig. 1 - Photomicrography of the epidermis of the hoof capsule of buffalo hooves. (A) Epidermal papillae from the coronary corium (yellow asterisk). (B) Abaxial wall papillae (yellow asterisk). (C) Sole papillae (yellow asterisk). (D) Basal layer of the laminar corium from the abaxial wall, showing intense mitotic division of the keratinocytes at the tip of the red arrow. (E) Basal layer (yellow asterisk), spiny layer (red arrow). (F) Granular layer (red arrow) and corneal layer (yellow asterisk), H\&E.

nucleus and is organized in an "umbrella" fashion, always in the opposite direction to the surface of the hoof capsule (Figs. 2. C, D). It is possible that this melanin arrangement might protect the DNA molecule from ultraviolet (UV) radiation, contributing in part to increase the resistance of the hoof capsule of buffalo hooves. Studies show that UV-B radiation, along with UV-C, might compromise the epidermis of derived structures, inducing the production of free radicals through the peroxidation of lipids, indirectly damaging the DNA. This mechanism might determine cell death and present a skin carcinogenic effect (da Silva et al., 2001).

It is imperative to have academic studies that describe the behavior of melanocytes and melanin concentration by area of the corneal tissue in pigmented and non-pigmented hulls. It is believed there is evidence that the melanocyte and melanin production can directly or indirectly influence the strength of this anatomic structure. Therefore, extrapolating these results to the cattle species, the same arguments can be used to justify the greater fragility observed in depigmented hooves when compared to pigmented hooves (Rabelo et al.). However, contrary to this study, those authors did not point to the disposition of the melanin pigment in an "umbrella" fashion as a possible protective factor for hoof DNA against UV radiation after analyzing the size, thickness and gaps between the epidermal papillae.

Histological analysis of the laminar corium epithelium showed that the keratinocytes from the horn layer are full of keratin (first product of keratinization) and arranged concentrically to form the corneal tubules. Intratubular keratin is arranged in a helical form and the keratinocytes are anucleated (Figs. 3. A, B, C). The helical arrangement of the intra tubular keratin, similar to the alfakeratin structure - main protein constituent of the keratinized 


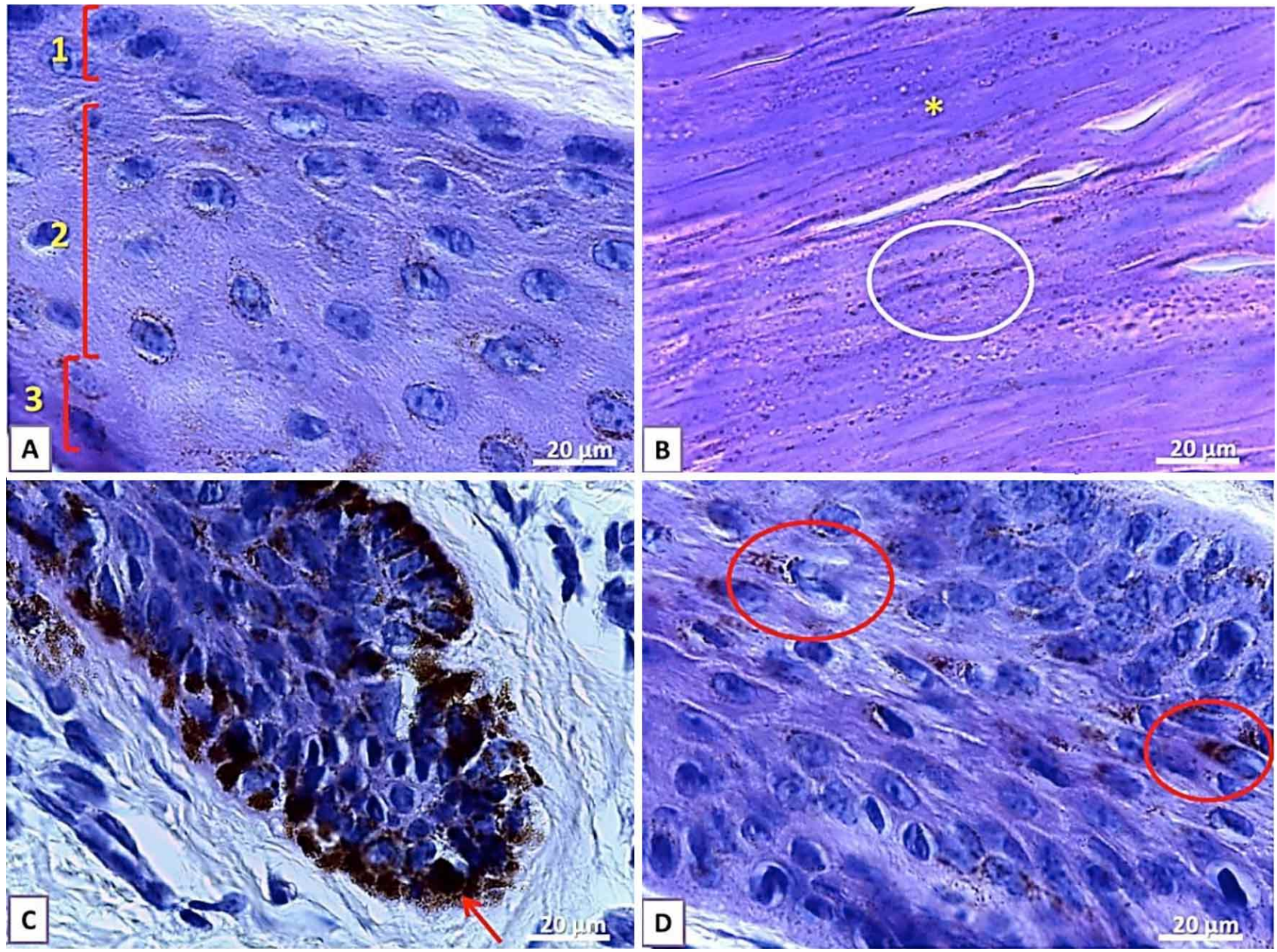

Fig. 2. Photomicrography of the coronary corium epidermis from the hoof capsule of buffalo hooves. (A) greater quantity of melanin in the keratinocytes near the epidermal papillae base and smaller quantity near the apex. (1) Basal layer, (2) Spiny layer, (3) Granular layer. (B) Keratinized epidermis (yellow asterisk). In the white circle numerous melanosomes can be noticed, spread in the keratinized tissue (white circle). (C) Intense melanin production at the base of the epidermal papillae of the coronary corium, and its release to the keratinocytes through the melanosomes (red arrow). (D) Melanosomes, rich in melanin and organized in an "umbrella" fashion, around the cell nucleus (red circle) H\&E.

epidermis - was also described by McKittrick et al. (2012). The intercellular cement, second product of keratinization, adhering the keratinocytes and helping in the waterproofing of the hoof capsule and observed in the present study, was not reported in other research with buffaloes (Silva et al.), yet it was described in equines (Hendry et al., 1999) (Fig. 4). Intense dermic vascular network formation around the epidermal papillae was also observed, in addition to papillary central vessels (Fig. 3, D and E).

Computerized light microscopy indicated that the corneal tubules of the dorsal and abaxial wall of the hoof capsule of buffalo hooves begin at the coronary corium and project from proximal to distal, following the same growth direction of the hoof, up to the white line.
This feature was also seen in the sole; however, the development of the corneal tubules in this region started at the laminar corium (Figs. 4. A, B). The same evaluation method revealed corneal tubules in a helical fashion (Figs. 4. C, D), agreeing with McKittric's et al. descriptions.

Technical hystomorphometry allowed the measurement of the length, width and numbers of thoracic and pelvic epidermal papillae, laterally and medially in different parts of the hoof capsule of buffalo's digits (Table I).

The length of the epidermal papillae in buffalo hooves, assessed through hystomorphometry did not reveal statistical differences in any of the comparisons ( $p>0.05$ ), but the values presented were higher in relation to the epidermal 

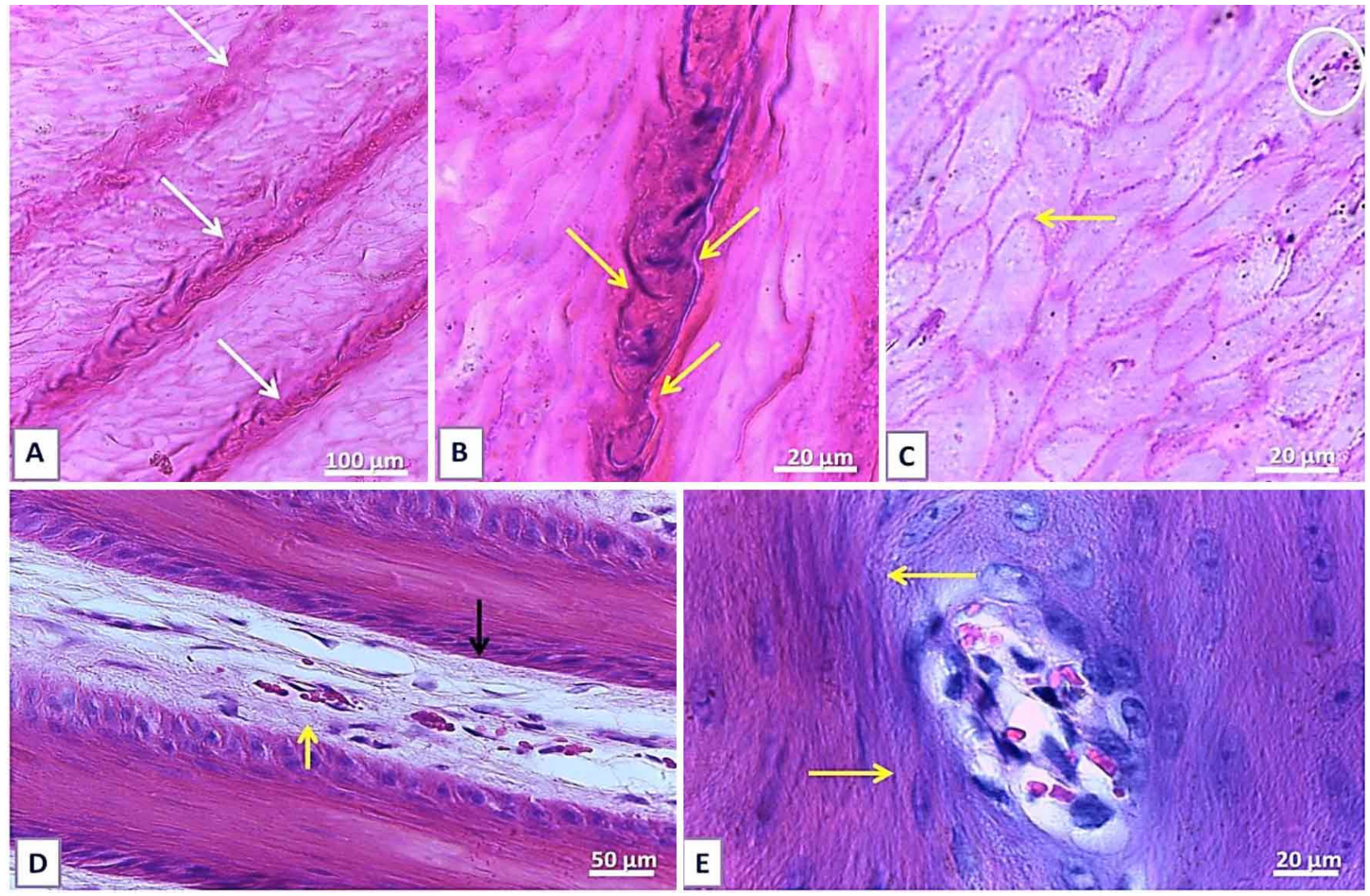

Fig. 3 - Photomicrography of the hoof capsule epidermis from buffaloes hooves. (A) Anucleate keratinocytes from the pre-bulbar hoof capsule, full of keratin, arranged concentrically forming the corneal tubules (white arrows). (B) Intra tubular keratin assumes a helical form (yellow arrows). (C) Extra tubular keratin, made up of anucleate keratinocytes firmly bonded by cement (yellow arrow) and inside the white circle melanin cytoplasmic granules can be seen. (D) The body of an epidermal papillae from the laminar corium of the abaxial wall, in a longitudinal cut, showing an afferent (yellow arrow) and efferent (black arrow) vessel. (E). Capillaries inside the epidermal papillae (yellow arrows). H\&E.

papillae of bovine hooves of the Gir and Holstein breeds (Rabelo et al.). As for the thickness of the epidermal papillae of the thoracic and pelvic digits, statistical differences were not seen in any of the comparisons ( $p>0.05)$. Similar data was the described by Mendonça et al. (2003), although the authors named the epidermal papillae with the name corneal tubules.

Table I. Mean $(\mu \mathrm{m})$ and standard deviation of the length, thickness and spacing between epidermal papillae of the hooves of buffalo.

\begin{tabular}{lccc}
\hline \multicolumn{1}{c}{ Region } & Papillae Length & Papillae Thickness & Papillae Gap \\
\hline TL & $1,657.079 \pm 412.673 \mathrm{a}$ & $59.027 \pm 13.056 \mathrm{a}$ & $52.585 \pm 14.039 \mathrm{a}$ \\
PL & $1,797.088 \pm 457.692 \mathrm{a}$ & $64.265 \pm 11.467 \mathrm{a}$ & $45.240 \pm 12.564 \mathrm{a}$ \\
TL-LD & $1,617.023 \pm 461.861 \mathrm{a}$ & $66.666 \pm 21.114 \mathrm{a}$ & $57.501 \pm 12.353 \mathrm{a}$ \\
PL-LD & $1,660.156 \pm 373.336 \mathrm{a}$ & $58.469 \pm 12.387 \mathrm{a}$ & $41.922 \pm 13.564 \mathrm{a}$ \\
TL-MD & $1,707.149 \pm 355.119 \mathrm{a}$ & $62.807 \pm 11.922 \mathrm{a}$ & $50.639 \pm 13.967 \mathrm{a}$ \\
PL-MD & $1,890.727 \pm 528.611 \mathrm{a}$ & $62.926 \pm 16.104 \mathrm{a}$ & $51.316 \pm 14.318 \mathrm{a}$ \\
CCOR & $1,800.717 \pm 264.216 \mathrm{a}$ & $95.667 \pm 17.451 \mathrm{ab}$ & $56.084 \pm 9.821 \mathrm{a}$ \\
ABW & $1,832.997 \pm 562.411 \mathrm{a}$ & $112.367 \pm 21.817 \mathrm{~b}$ & $76.999 \pm 14.910 \mathrm{~b}$ \\
SOL & $1,522.238 \pm 379.704 \mathrm{a}$ & $89.401 \pm 27.496 \mathrm{a}$ & $55.972 \pm 13.056 \mathrm{a}$ \\
\hline MEAN & $\mathbf{1 , 7 2 1 . 5 9}$ & $\mathbf{6 2 . 9 4}$ & $\mathbf{4 9 . 0 2}$
\end{tabular}

The means followed by the same letter on the same column and variable are not different $(\mathrm{p}>0.05)$. CCOR - coronary corium; $\mathrm{ABW}$ - abaxial wall; TL - thoracic limb; PL - pelvic limb; TL-LD - thoracic limb lateral digit; MP-DL - pelvic limb lateral digit; TL-MD - thoracic limb medial digit; PL-MD - pelvic limb medial digit; SOL - sole.[S6] 

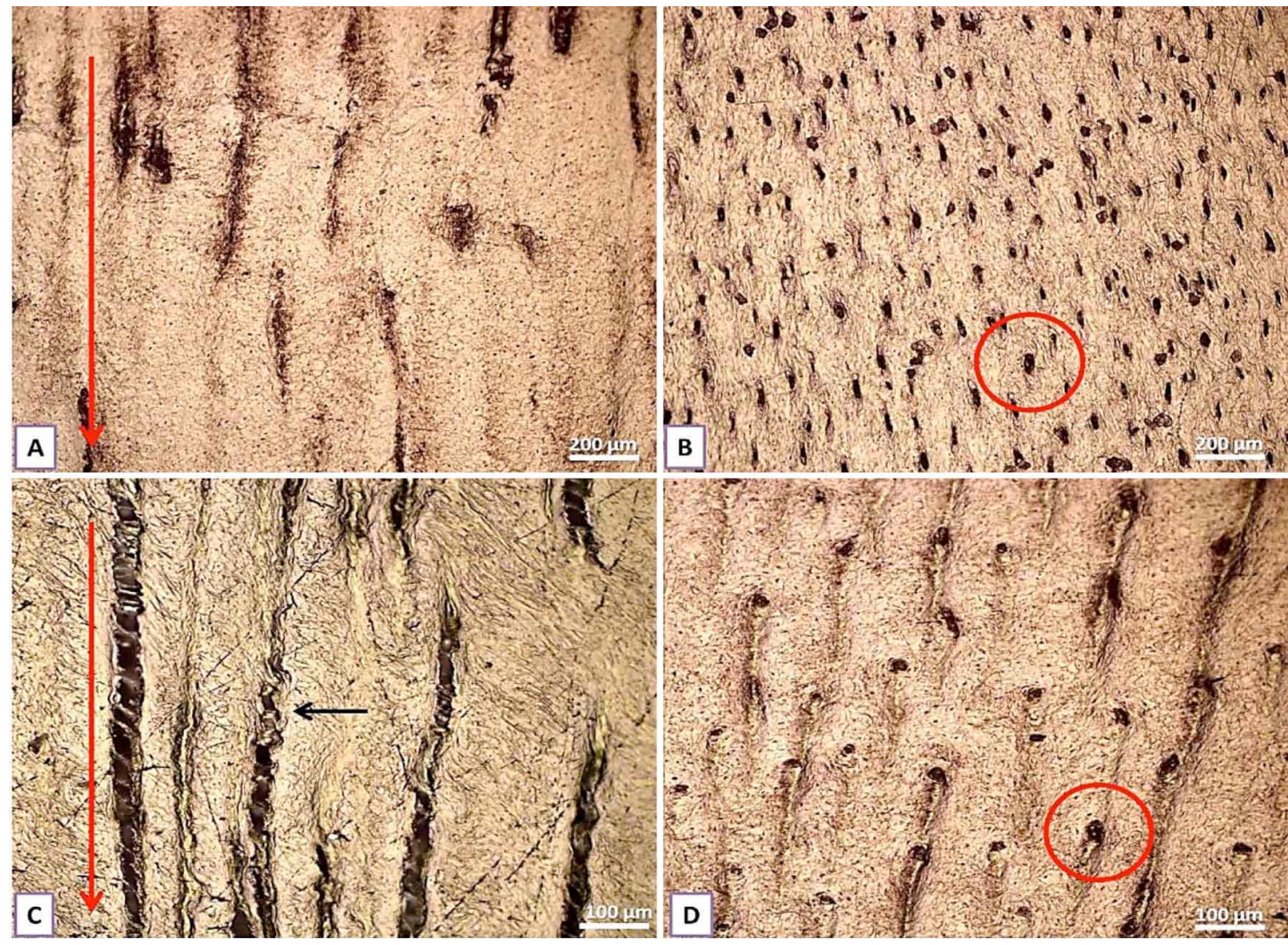

Fig. 4 . Photomicrography of the keratinized epidermis from the hoof capsule of buffaloes. (A). Frontal view of a fragment of the hoof capsule abaxial wall. It can be seen that the corneal tubules are arranged alongside each other, and they follow the hoof growth direction, from proximal to distal (red arrow). (B) Transversal cut showing the corneal tubules in a circular fashion (red circle). (C) Lateral view of a fragment of the hoof capsule with the corneal tubules arranged alongside each other, following the hoof growth direction (red arrow). It can be observed that the corneal tubules are disposed in a helical fashion (black arrow). (D) Frontal view of a fragment of the hoof capsule sole with the corneal tubules in a circular arrangement (red circle).

The mean values of papillae at the coronary corium, abaxial wall and sole thickness of the hoof thoracic and pelvic parts in this assessment, sole papillae were less thick, with a significant difference between the means obtained for the abaxial wall and sole $(\mathrm{p}<0.05)$. Previous research in cattle suggests that thicker papillae, would theoretically present a larger capacity for keratin production (Rabelo et al.).

This study revealed that the coronary corium shows a greater number of epidermal papillae per area in comparison to the laminar corium of the abaxial wall and sole (Table II).

This finding might be justified, in part, by the fact that the wall and sole laminar corium are not responsible for the hoof growth, but for shock absorption. It is possible that this feature of the sole explains the fact that the epidermal papillae are less thick and less numerous in this region. When the means of the coronary corium, abaxial wall and sole of the thoracic and pelvic hoof parts were compared, there was statistical difference $(\mathrm{p}<0.05)$, demonstrating superior values in the gaps between the abaxial wall papillae in relation to the coronary corium and sole. Previous researches showed these means in other species. Nevertheless, this paper indicates that the buffaloes have a higher length and papillae number per linear area. Although it is not possible to compare this data statistically, it is believed that these anatomical structures, in the buffalo species, have greater keratin production capacity, in addition to promoting better epidermal fixation to the hoof capsule.

Table II. Mean $(\mu \mathrm{m})$ and standard deviation, linear measurement of papillae number/mm of the coronary and laminar corium of buffalo hooves.

\begin{tabular}{lc}
\hline Hoof c apsule regions & Papillae number $/ \mathbf{2 0 0 0} \boldsymbol{\mu m}$ \\
\hline Coronary corium & $16 \pm 0.121 \mathrm{a}$ \\
Abaxial wall & $13 \pm 0.143 \mathrm{~b}$ \\
Sole & $13 \pm 0.115 \mathrm{~b}$ \\
MEAN & $\mathbf{1 4}$ \\
\hline
\end{tabular}

Means followed by the same letter on the same column are not different $(\mathrm{p}>0,05)$. 


\section{CONCLUSION}

Thanks to this study it was possible to generate not yet described parameters in the scientific literature concerning the microstructural aspects of the buffaloes' hoof capsule. To achieve these results, we used unconventional techniques in the field of veterinary medicine, such as hystomorphometry and computerized light microscopy. The relevance of the enlightened data generates a new perspective on the buffaloes and cattle podiatry, thus allowing a better comprehension about the hoof's morphology and its influence on the hoof capsule's resistance.

ASSIS, B. M.; VULCANI, V. A.; SANT'ANA, F. J. F.; SILVA, L.A. F.; LIMA, C. R. O.; SANTA RITA, R. M. \& RABELO, R. E. Características histológicas y morfométricas de la capa cornea de las cápsulas del casco de búfalo. Int. J. Morphol., 35(4):12911297, 2017.

RESUMEN: El objetivo del estudio fue evaluar la microestructura de la cápsula del casco del búfalo mediante histomorfometría y microscopía óptica computarizada. Se describe la longitud, el espesor, el espacio y el número de papilas epidérmicas y la morfología de los túbulos corneales del casco. Utilizamos 56 cápsulas de cascos de 14 hembras adultas entre 24 a 60 meses de edad de la raza Jafarabadi, cuyo peso aproximado era de $650 \mathrm{~kg}$. Analizamos 56 cascos, 28 del miembro torácico y 28 del miembro pélvico, con un total de 112 dedos. Se recogieron especímenes clínicos en el corion coronario, corion laminar de la pared abaxial y suelas pre-bulbares. Concluimos que la microestructura de la cápsula de los cascos de los búfalos está formada por papilas epidérmicas de 1.721,59 mm de longitud, 62,94 mm de espesor y 49,02 mm de espacio entre papilas. Se determinó que el corion coronario tiene más papilas epidérmicas que el corion laminar de la pared axial y las suelas pre-bulbares. Los túbulos córneos de las cápsulas de casco presentan una forma helicoidal y existe la posibilidad de que esta característica también se aplique a las pezuñas de otras especies de animales biungulados. También se determinaron algunos parámetros morfológicos no descritos en la literatura científica. Estos hallazgos pueden ser útiles en estudios comparativos de ganado bovino y bubalino saludable y en consideración de la 'vulnerabilidad' frente a diferentes enfermedades del casco.

PALABRAS ClAVE: Histomorfometría; Papilas epidérmicas; Queratinocitos; melanocitos; Túbulos córneos.

\section{REFERENCES}

da Silva, R. G.; La Scala Jr., N. \& Pocay, P. L. B. Transmissão de radiação ultravioleta através do pelame e da epiderme de bovinos. Rev. Bras. Zootec., 30(6):1939-47, 2001.

Greenough, P. R. Bovine Laminitis and Lameness: A Hands-On Approach.
Philadelphia, Saunders Elsevier, 2007.

Guccione, J.; Carcasole, C.; Alsaaod, M.; D’Andrea, L.; Di Loria, A.; De Rosa, A.; Ciaramella, P. \& Steiner, A. Assessment of foot health and animal welfare: clinical findings in 229 dairy Mediterranean Buffaloes (Bubalus bubalis) affected by foot disorders. B. M. C. Vet. Res., 12(1):107, 2016.

Hendry, K. A.; MacCallum, A. J.; Knight, C. H. \& Wilde, C. J. Effect of endocrine and paracrine factors on protein synthesis and cell proliferation in bovine hoof tissue culture. J. Dairy Res., 66(1):23-33, 1999.

König, H. E.; Liebich, H. G. \& Bragulla, H. Veterinary Anatomy Of Domestic Mammals. Textbook and Colour Atlas. $3^{\text {rd }}$ ed. Stuttgart, Schattauer, 2007.

McKittrick, J.; Chen, P. Y.; Bodde, S. G.; Yang, W.; Novitskaya, E. E. \& Meyers, M. A. The structure, functions and mechanical properties of keratin. J. O. M., 64(4):449-68, 2012.

Mendonça, A. C.; Da Silva, F.; Fioravante, M. C. S.; de Moraes, J. O. R.; Almeida, C. F.; Oliveira, K. S.; Oliveira, M. P. \& Da Silva, L. M. Aspectos morfológicos dos dígitos de bovinos das raças Gir e Holandesa. Cienc. Anim. Bras., 4(1):53-60, 2003.

Rabelo, R. E.; Vulcani, V. A. S.; Sant'Ana, F. J. F.; Silva, L. A. F.; Assis, B. M. \& Araújo, G. H. M. Microstructure of Holstein and Gir breed adult bovine hooves: histomorphometry, three-dimensional microtomography and microhardness test evaluation. Arq. Bras. Med. Vet. Zootec., 67(6):1492-500, 2015.

Sampaio, I. B. M. Estatística Aplicada à Experimentação Animal. $3^{\mathrm{a}} \mathrm{ed}$. Belo Horizonte, Fep-Mvz, 2010.

Silva, L. A. F.; Campos, S. B. S.; Rabelo, R. E.; Vulcani, V. A. S.; Noronha Filho, A. D. F. \& de Freitas, S. L. R. Morfometric comparative analysis of the hoof of Nelore, Pantaneira and Curraleira breeds of cattle and buffaloes and their relationship with the pathogenesis of digital diseases. Pesq. Vet. Bras., 35(4):377-84, 2015.

Tombolato, L.; Novitskaya, E. E.; Chen, P. Y.; Sheppard, F. A. \& McKittrick, J. Microstructure, elastic properties and deformation mechanisms of horn keratin. Acta Biomater., 6(2):319-30, 2010.

\section{Corresponding author}

Prof. Dr. Rogério Elias Rabelo

Clínica e Cirurgia de Grandes Animais

Universidade Federal de Goiás

Regional Jataí - Unidade Jatobá

BR 364, km 192, n 3.800 - St. Parque Industrial

CEP: 75.801 .615 - Jatai/GO

64-36068326

BRAZIL

E-mail: rabelovet@yahoo.com.br

Received: 28-03-2017

Accepted:13-07-2017 